\title{
Pengaruh Love Of Money, Machiavellian, dan Idealisme Pada Persepsi Etis Mahasiswa Akuntansi
}

\author{
Putu Pandhu Prabowo ${ }^{1}$ \\ A.A.G.P Widanaputra ${ }^{2}$
}

\author{
${ }^{1}$ Fakultas Ekonomi dan Bisnis Universitas Udayana (Unud), Bali, Indonesia \\ email: putupandhu@gmail.com / Tlp.+6287761616870 \\ ${ }^{2}$ Fakultas Ekonomi dan Bisnis Universitas Udayana (Unud), Bali, Indonesia
}

\begin{abstract}
ABSTRAK
Kode etik penting dimiliki oleh seorang akuntan dalam mengambil keputusan. Namun, pada praktiknya banyak akuntan yang masih bekerja tanpa menggunakan kode etik profesional. Menentukan kredibilitas dan integritas seorng akuntan dapat tercermin dari perilaku etis akuntan tersebut. Etika profesi sangat penting dimiliki oleh seorang akuntan, maka fokus pengembelajaran etika profesi kepada mahsiswa akuntansi sangatlah penting karena mahasiswa akuntansi merupakan titik awal pengembangan dari profesi akuntansi. Tujuan penelitian ini adalah untuk mengetahui pengaruh love of money, machiavellianisme, dan idealisme pada persepsi etis mahasiswa akuntansi. Metode penentuan sampel dilakukan dengan teknik purposive sampling. Populasi penelitian ini yaitu 200 orang Mahasiswa Program Studi Akuntansi angkatan 2014 Fakultas Ekonomi Universitas Udayana yang telah menempuh mata kuliah akuntansi perilaku, sampel yang diambil untuk penelitian adalah 200 orang. Teknik analisis data yang digunakan yaitu regresi linear berganda. Hasil penelitian yaitu love of money berpengaruh negatif pada persepsi etis. Machiavellian berpengaruh negatif pada persepsi etis. Idealisme berpengaruh positif pada persepsi etis.
\end{abstract}

Kata kunci: Love of money, Machiavellian, idealism, persepsi etis.

\begin{abstract}
Every accounting profession must work and make decisions based on existing codes of ethics. However, in practice there are still many accounting professionals who work without a professional code of ethics. The ethical behavior of an accountant is necessary in determining the integrity and credibility in the field of accounting. The importance of ethics in a profession makes the accounting profession focusing its attention on the ethical perceptions of accounting students as a starting point in improving perceptions of the accounting profession. The purpose of this study is to determine the influence of love of money, machiavellianism, and idealism on the ethical perception of accounting students. The method of determining the sample is done by purposive sampling technique. The population of this research is student of Accounting Study Program of class 2014 in Faculty of Economics Udayana University of Bali which amounts to 200 people, the sample taken amounted to 200 people, who has taken courses in behavioral accounting. The data analysis used to test the hypothesis is by using simple linear regression analysis technique and multiple linear regression. The results show that love of money negatively affects the ethical perception. Machiavellian and idealism have a positive effect on ethical perceptions.
\end{abstract}

Keywords: Love of money, machiavellian, idealism, ethical perception. 
Putu Pandhu Prabowo dan A.A.G.P Widanaputra. Pengaruh...

\section{PENDAHULUAN}

Setiap individu dan kelompok umumnya memiliki nilai menjadi pedoman dalam masyarakat. Nilai etika dalam masyarakat memperkecil timbulnya permasalahan dan pihak terkait yang tidak diuntungkan dalam suatu kelompok. Etika terkait dengan sebuah sikap moral dalam mengambil suatu keputusan dasar tentang salah atu benarnya perilaku. Pentingnya etika akan terasa saat unsur-unsur etis ketika menyatakan pendapat mengalami perbedaan. Dengan demikian, untuk mengambil tindakan yang tepat, etika dalam berperilaku sangat penting.

Menurut Jalaludin Rakhmat (1999), persepsi merupakan sebuah pengalaman mengenai peristiwa, objek, atau hubungan yang didapat dari kesimpulan sebuah informasi dan pesan yang ditafsirkan. Persepsi merupakan suatu hal yang penting sebagai sebuah awal informasi yang masuk dari sebuah situasi atau lingkungan (Rowe dan Boulgarides, 1992). Terdapat pandangan mengenai hal apa saja yang memengaruhi perilaku individu yang etis (Purnamasari, 2006).

Keputusan yang tidak etis timbul karena adanya pengaruh dari karakter individu dan juga lingkungan. Menurut Utami (2005) dalam perusahaan terdapat fakor-faktor yang memengaruhi sebuah keputusan atau perilaku tidak etis yaitu kebutuhan setiap individu yang berbeda, individu yang faktor yang berpengaruh pada keputusan atau tindakan tidak etis antara lain kebutuhan setiap individu, individu tidak memiliki pedoman dalam dirinya, kebiasaan dari individu tersebut, tidak etisnya lingkungan disekitar, dan tindakan dari atasan yang membuat setiap individu dalam perusahaan berperilaku tidak etis. 
Murwanto (2007) menyatakan bahwa etika terkait dengan prinsip moral dan perbuatan yang melandasi tindakan seseorang sehingga tindakan yang diambil dianggap sebagai suatu perbuatan yang terpuji dan dapat memberikan rasa hormat bagi individu tersebut di masyarakat. Berbagai macam etika akan tumbuh dan berkambang dalam kehidupan bermasyarakat. Menurut Lois O. Katt Soff (1953) terdapat dua etika yang berkembang dimasyarakat yaitu pertama etika deskriptif, adalah menjelaskan mengenai kenyataan terkait perilaku dan nilai individu dalam suatu keadaan dan realita budaya kehidupan bermasyarakat. Kedua yaitu etika normatif yang menghimbau serta memberikan penilaian terhadap individu mengenai berperilaku sesuai peraturan dan norma dalam masyarakat.

Mempelajari perilaku dalam profesi akuntansi sangat penting menggunakan pertimbangan etis karena kepercayaan dan nilai perilaku individu terkait dengan penilaian profesional (Elias, 2008). Mempertahankan standar etika yang tinggi sangat diperlukan, karena meningkatnya persaingan menyebabkan profesi akuntansi akan terus berhadapan dengan tekanan. Profesi akuntansi dalam menjalankan tugas dan membuat keputusan harus didasari kode etik yang ada. Realitanya profesional akuntansi banyak yang masih bekerja tidak didasari pada kode etik profesional.

Kredibilitas serta integritas menjadi sangat penting dalam menentukan perilaku etis seorang akuntan. Profesi akuntan sangat dekat serta rawan terkait tindakan kecurangan. Kasus tentang masalah keuangan banyak terjadi pada perusahaan-perusahaan besar dan pelaku akuntan internasional sering terjadi 
Putu Pandhu Prabowo dan A.A.G.P Widanaputra. Pengaruh...

belakangan ini, akibatnya adalah keprcayaan kepada profesi akuntan menurun di mata masyarakat.

Salah satu kasus yang melibatkan profesi akuntan terjadi pada perusahaan besar yaitu Enron dan Worldcom. Perusahaan tersebut memanipulasi laporan keuangan (window dressing) untuk menunjukan kinerja perusahaan terlihat baik dan melakukan kerjasama dengan pihak kantor akuntan publik. Saham Enron yang semakin tinggi terjadi karena adanya manipulasi laporan keuangan selama beberapa tahun. Kerugian yang terjadi diakibatkan KAP Arthur Andersen memanipulasi laporan keuangan perusahaan Enron (Arens et al., 2006:87). Kesimpulan dari kasus tersebut yaitu adanya pelanggaran dari etika profesi akuntan, pelanggaran pada prinsip perilaku profesional, integritas, dan tanggung jawab profesi.

Salah satu kasus pelanggaran etika profesi akuntan di Indonesia, yaitu laporan keuangan PT KAI tahun 2005 disinyalir telah dimanipulasi oleh pihakpihak tertentu. Manipulasi laporan keuangan PT Kereta Api Indonesia tahun 2005 diduga telah dilakukan oleh pihak-pihak tertentu, hal ini jelas melanggar etika profesi akuntan. Kecurangan PT KAI sebenarnya sudah terjadi pada tahun sebelumnya, dimana PT KAI mengalami kerugian Rp 63 miliar namun sebaliknya PT KAI justru mengumumkan keuntungan sebesar Rp 6,90 miliar. Bukti penyimpangan standar akuntansi keuangan ada pada piutang tak tertagih (http://www.tempo.com). Bedford Committee menyatakan seharusnya nilai tentang integritas, kredibilitas, dan standar etik dalam profesi akuntansi ditanamkan kepada mahasiswa (Normadewi, 2012). 
Pendidikan tentang kepedulian pada etika seharusnya menjadi pelajaran dasar sebelum seorang mahasiswa memasuki dunia profesi akuntansi. Pemahaman serta pelajaran etika yang baik akan membawa keuntungan bagi mahasiswa di masa depan (Normadewi, 2012). Penelitian yang bertujuan untuk sosialisasi tentang etika akuntansi masih sangat dibutuhkan, hal ini diharapkan agar mahasiswa memiliki pemahaman persepsi etis yang baik sebagai modal awal untuk meningkatkan persepsi terhadap profesi. Etika sangat penting dalam profesi akuntansi sehingga fokus perhatian pada persepsi etis mahasiswa akuntansi telah dibentuk sejak awal untuk menghindari pelanggaran terhadap etika profesi akuntan. Normadewi (2012) menyatakan penelitian dan sosialisasi terkait etika kepada mahasiswa akuntansi sangat penting dilakukan.

Berdasarkan pemaparan kasus diatas yang terkait dengan tindakan memanipulasi laporan keuangan, menunjukan rendahnya etika dan moral dari pihak-pihak pembuat keputsan. Nilai etika yang baik dapat meminimalisir adanya penyimpangan perilaku dalam profesi akuntan. Menciptakan moral dan karakter individu yang baik diawali dengan menanamkan nilai etika sejak dini.

Pendidikan terkait etika harus sangat diperhatikan dan diterapkan dengan benar agar mahasiswa memiliki karakter yang berpedoman pada nilai etika, sehingga dapat menjadi individu yang memiliki etika profesi yang sesuai sebelum masuk ke dunia kerja. Etika adalah suatu sikap moral terkait sebuah keputusan yang diambil. Seringnya akuntan berada pada suatu keadaan yang penuh konflik kepentingan membuat akuntan berada dibawah tekanan dan sulit dalam mengambil keputusan. Persaingan bisnis yang tinggi dan adanya konflik 
Putu Pandhu Prabowo dan A.A.G.P Widanaputra. Pengaruh...

kepentingan, membuat akuntan harus memiliki nilai etis dan tetap menjaga kejujuran.

Salah satu faktor yang memengaruhi perilaku etis seseorang adalah uang. Uang merupakan aspek yang sangat penting dalam kehidupan sehari-hari. Studi oleh Mitchell dan Mickel (1999), uang berhubungan dengan kepribadian individu dan merupakan variabel sikap. Ellias (2009) memaparkan bahwa di Amerika, uang dan pendapatan menjadi tolok ukur dalam melihat kesuksesan seseorang. Herzeberg (1987) menyatakan bahwa uang menjadi motivasi untuk sebagian orang, akan tetapi bagi orang lain uang merupakan sebuah factor kesehatan (hygene factor).

Tang (2008) melakukan penelitian dengan melakukan pengujian variabel psikologis yang baru yakni cinta individu pada uang (love of money). Love of money digunakan sebagai konsep dalam menilai subjektifnya perasaan seseorang terhadap uang. Tang (2008) menyatakan love of money adalah suatu sikap seseorang kepada orang lain dan keinginan serta aspirasi terhadap uang. Kecintaan akan uang dapat dibedakan berdasarkan kebutuhan setiap individu dan adanya pengaruh dari beberapa faktor seperti demografi yang meliputi jenis kelamin, umur, pendidikan, strata sosial dan ekonomi, dan latar belakang etnis.

Penelitian mengenai sikap kecintaan manusia pada uang telah banyak dilakukan dan memperoleh hasil yang berbeda. Yamauchi dan Tampler (1982) menemukan sebuah konsep untuk mengukur money attitude, yaitu Money Attitude Scale (MAS), terdiri dari empat faktor yakni kepemilikan, kekuasaan, kecemasan, dan ketidakpercayaan. Hayes (2006) mengungkapkan beberapa faktor lain yang 
memengaruhi love of money yakni seperti kemampuan, ketidakcukupan, jaminan, hak miliki, kekuasaan, dan obsesi. Penelitian mengenai love of money menyatakan bahwa love of money berhubungan dengan perilaku dalam organisasi baik yang tidak diinginkan maupun yang diinginkan.

Penelitian Richmond (2003) mendapatkan bukti adanya sifat individu yang memengaruhi perilaku etis. Investigasi yang dilakukan Richmond (2003) mengenai suatu paham machiavellianisme sebagai bentuk suatu kepribadian yaitu machiavellian, dan pertimbangan etis terkait cenderungnya sifat individu dalam menyelesaikan dilema etis. Penelitian ini mendapatkan hasil yaitu pertama, tingginya sifat Machiavellian dapat menimbulkan perilaku yang tidak etis. Kedua, tingginya pertimbangan etis, menyebabkan orang akan berperilaku semakin etis.

Idealisme adalah suatu tindakan dengan asumsi bahwa tepatnya suatu tindakan dapat memberikan konsekuensi atau hasil yang diharapkan (Falah, 2006). Individu yang idealis akan menghindar dari tindakan yang membawa kerugian bagi orang-orang sekitar dan mereka tidak akan bertindak yang memiliki konsekuensi negatif, dimana dalam setiap langkah yang diambil menunjukkan keberpihakan kepada nilai moral pada masyarakat dan tidak melanggar nilai-nilai yang berlaku tersebut (Sumiyantini, 2017).

Menurut Smith (2009), ketika memberikan respon karena danya peilaku tidak etis,indivisu yang memiliki sikap tidak etis harus dapat menjawab tidak setuju.Individu yang memiliki idealism tinggi umumnya tidak setuju atau menolak perilaku yang dianggap tidak etis. Idealisme yang tinggi dapat menyebabkan semakin rendahnya perilaku yang tidak etis. Dalam situasi mengenai perilaku 
Putu Pandhu Prabowo dan A.A.G.P Widanaputra. Pengaruh...

tidak etis yang melibatkan akuntan, seseorang yang memiliki idealisme tinggi akan cenderung memberikan tanggapan ketidaksetujuan atas perilaku tidak etis yang terjadi dan tindakan yang diambil akan bersifat tegas atas kejadian tidak etis pada akuntan.

Berdasarkan uraian diatas, peneliti termotivasi untuk melakukan penelitian mengenai pengaruh love of money, machiavellian, dan idealism pada persepsi etis mahasiswa akuntansi. Beberapa penelitian mengenai perspsi etis telah dilakukan dengan mengidentifikasi faktor-faktor yang mempengaruhinya, namun hasil yang diperoleh berbeda-beda sehingga fenomena ini menarik untuk diuji kembali. Rumusan masalah penelitian ini yaitu bagaimana hubungan love of money, machiavellian, dan idealisme pada persepsi etis mahasiswa akuntansi. Penelitian ini bertujuan untuk memperoleh bukti empiris pengaruh pengaruh love of money, machiavellian, dan idealism pada persepsi etis mahasiswa akuntansi.

Manfaat teoritis penelitian ini adalah diharapkan para pendidik di bidang akuntansi untuk menerapkan dan mengembangkan pendidikan tentang etika dengan lebih memperhatikan moral ataupun pertimbangan etis mahsiswa agar membentuk karakter etis sebagai calon akuntan. Manfaat praktis penelitian ini penelitian ini adalah memberikan pertimbangan kepada manajemen perusahaan dalam menemukan pekerjaan sebagai akuntan yang dalam rekruitmennya perlu persepsi etis.

Kajian pustaka pada penelitian ini yaitu teori sikap dan perilaku dikembangkan oleh Triandis (1971), teori ini menyatakan bahwa perilaku ditentukan oleh bagaimana orang tersebut bersikap sesuai keinginan mereka, 
aturan-aturan sosial yang terkait dengan mereka lakukan dan pikirkan serta kebiasaan yang biasa mereka lakukan dengan memikirkan konsekuensi dari perilaku.

Berdasarkan permasalahan yang telah dikemukakan, kajian teoritis, dan tinjauan penelitian terdahulu dapat digambarkan kerangka konseptual pada penelitian ini adalah sebagai berikut.

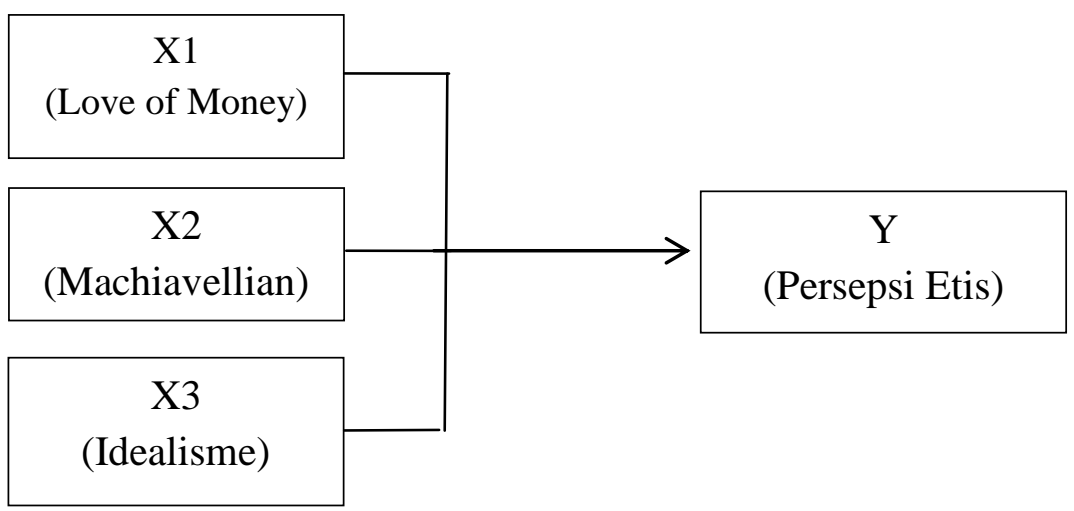

Gambar 1.

Kerangka Konseptual

Uang sangat penting dalam kehidupan sehari-hari manusia, dimana uang merupakan suatu faktor penting dalam kehidupan manusia. Motivasi dan sifat manusia dalam melakukan pekerjaan didasari kebutuhan seseorang terhadap uang. Gambaran tentang love of money dekat dengan sifat serakah, sehingga ketika individu memiliki kertarikan tinggi terhadap uang, maka biasanya individu itu termasuk orang yang serakah. Ketertarikan yang berlebihan terhadap uang biasanya akan berpengaruh pada sifat seseorang dan akan menilai segala sesuatunya berdasarkan uang. Penelitian Charismawati (2011) melihat pengaruh love of money pada persepsi etika mahasiswa menyatakan adanya hubungan dari 
Putu Pandhu Prabowo dan A.A.G.P Widanaputra. Pengaruh...

love of money pada mahasiswa akuntansi serta persepsi etis yang mereka miliki. Love of money mahasiswa yang semakin tinggi, menyebabakan persepsi etisnya semakin rendah.

$\mathrm{H}_{1}$ : Semakin tinggi kecenderungan love of money seseorang maka semakin rendah persepsi etisnya.

Richmond (2001) mendeskripsiskan perilaku Machiavellian adalah perilaku tidak memiliki terkait hubungan secara personal, moral konvensional yang diabaikan, dan rendahnya komitmen mengenai ideologi. Umumnya sifat Machiavellian berkaitan dengan sifat manipulative dari individu, untuk mencapai tujuannya individu sangat bersihat persuasive, dan sangat agresif. Perilaku machiavellian, samangat mudah melakukan manipulasi terhadap orang lain dan tidak menghargai adanya individu lain. Seorang akuntan penting dalam memiliki kualitas untuk menjaga integritasnya dan tepatnya keputusan etis yang dapat dibuat. Penelitian Yeltsinta (2013) mendapatkan hasil dimana perilaku machiavellian auditor yang tinggi dapat menyebabkan melakukan penyimpangan pada persepsi etis. Perilaku Machiavellian yang tinggi menyebabkan persepsi etis semakin rendah. Terdapat pengaruh negatif perilaku machiavellian dengan presepsi etis. Artinya, seseorang dengan perilaku machiavellian yang tinggi, maka presepsi etisnya semakin rendah.

$\mathrm{H}_{2}$ : Semakin tinggi kecenderungan perilaku machiavellian, maka presepsi etisnya semakin rendah.

Individu yang memiliki sifat idealis memiliki prinsip, dimana merugikan orang lain dapat dihindari dengan tidak mengambil tindakan yang memiliki konsekuensi negartif atau memiliki risiko. Apabila ada dua pilihan dan kedua pilihan tersebut memiliki dampak negative terhadap orang lain, maka individu 
dengan pemikiran yang idealis akan mengambil pilihan yang tidak merugikan orang lain.

Hasil penelitian menyatakan individu yang idealis akan mengambil sikap yang tegas pada suatu keadaan yang dapat merugikan orang lain. Individu yang idealis memiliki pandangan serta sikap yang tegas kepada individu yang melakukan pelanggaran perilaku etis. Penelitian Dzakirin (2013), Nurcahyo (2012), Comunale (2006) menyatakan idealisme tinggi yang dimiliki mahasiswa dapat penafsiran yang negative dari skandal yang dibuat oleh akuntan.

$\mathrm{H}_{3:}$ Semakin idealis seseorang maka semakin rendah persepsi etisnya.

\section{METODE PENELITIAN}

Desain penelitian yang dipergunakan pada penelitian ini yaitu pendekatan kuantitatif asosiatif. Metode penelitian kuantitatif merupakan metode yang berdasarkan fakta di lapangan dan dipergunakan dalam penelitian sampel atau populasi tertentu. Pendekatan kuantitatif asosiatif dengan tipe kausalitas merupakan adalah penelitian yang memberikan penjelasan adanya pengaruh dari variabel independen dengan variabel dependennya (Sugiyono, 2016: 12).

Lokasi penelitian yaitu di Fakultas Ekonomi dan Bisnis Universitas Udayana dengan responden dari mahasiswa akuntansi angkatan 2014. Penelitian ini dilakukan pada bulan September-Desember 2017. Pada penelitian ini yang menjadi objek adalah pengaruh love of money, machiavellian, dan idealisme pada persepsi etis mahasiswa akuntansi. Data diperoleh dengan menyebar kuesioner kepada mahasiswa akuntansi Fakultas Ekonomi dan Bisnis Universitas Udayana angkatan 2014. 
Putu Pandhu Prabowo dan A.A.G.P Widanaputra. Pengaruh...

Jenis data pada penelitian ini yaitu data kuantitatif. Pada penelitian ini data kuantitatif didapatkan dengan menggunakan dari hasil scoring berdasarkan jawaban para responden terhadap kuesioner yang telah diberikan. Adapun sumber data dari penelitian ini yaitu data primer. Data primer merupakan data penelitian data yang langsung diperoleh dari sampel penelitian (Sugiyono, 2016:129). Data primer didapat dengan menyebar kuesioner yang terstruktur agar mendapat informasi yang dibutuhkan untuk penelitian.

Metode penentuan sampel yang digunakan adalah purposive sampling. Kriteria sampel pada penelitian ini adalah mahasiswa program studi akuntansi Fakultas Ekonomi dan Bisnis Universitas Udayana angkatan 2014 yang sudah mengambil mata kuliah Akuntansi Keperilakuan. Kuisioner yang disebarkan kepada mahasiswa dihitung dengan skala likert, pilihan jawaban responden akan diberi nilai dengan skala 4 poin sebagai skor tertinggi dengan skala 1 untuk skor terendah dengan mengisi kolom. Jawaban Sangat Setuju (SS) diberi skor 4, jawaban Setuju (S) diberi skor 3, jawaban Tidak Setuju (TS) diberi skor 2, dan awaban Sangat Tidak Setuju diberi skor 1

Variabel terikat pada penelitian ini yaitu persepsi etis mahasiswa akuntansi. Presepsi etis diukur dengan menggunakan metode yang dikembangkan oleh Kelly Richmond (2001). Alat uji yang digunakan adalah Ethical Rating (ERATING), yang berisi pernyataan sebanyak 8 buah diukur menggunakan skala likert 1 sampai 4. Tindakan sangat etis dimulai dari poin 1 (sangat tidak setuju), sampai tindakan yang sangat tidak etis mendapat poin 4 (sangat setuju). 
Pada penelitian ini variabel bebas terdiri dari love of money, machiavellian, dan idealisme. Variabel love of money diukur menggunakan metode yang dikembangkan oleh Tang (2008) yaitu Money Ethics Scale (MES). Kuesioner yang dipergunakan menghasilkan sepuluh faktor berikut : richness, happiness, power of control, social influence, self expression, success, evil, dan budget. Pernyataan responden dengan pendapat setuju atau tidak atas pernyataan dinilai pada skala 1-4 poin, mulai dari 1 menyatakan sangat tidak setuju sampai 4 menyatakan sangat setuju. Pada masing-masing factor, skor dihitung terpisah. Apabila skor yang didapat semakin besar maka sifat love of money responden dinilai tinggi.

Pengukuran variabel machiavellian menggunakan skala Mach IV, dimana terdapat pernyataan sebanyak 20 item dan dihitung menggunakan skala likert dari skor 1 menyatakan sangat tidak setuju sampai skor 4 menyatakan sangat setuju. Perilaku Machiavellian responden yang tinggi maka akan terlihat pada skor yang tinngi pula. Pada penelitian ini terdapat pernyataan yang saat tabulasi skornya dibalik, karena pernyataan tersebut memliki sifat positif, yaitu perilaku machiavellian rendah skornya akan tinggi, maka skor harus dibalik (Reversed Scored).

Idealisme dihitung menggunakan skala likert 1 sampai 4. Skor 1 menyatakan sangat tidak setuju sampai skor 4 menyatakan sangat setuju. Individu yang setuju dengan pernyataan dianggap memiliki idealisme tinggi, sedangkan individu dianggap memiliki idealisme yang rendah apabila menyatakn tidak setuju dengan pernyataan tersebut. 
Putu Pandhu Prabowo dan A.A.G.P Widanaputra. Pengaruh...

Analisis linier berganda digunakan dalam tenik analisis data penelitian ini. Analisis linier berganda adalah pengujian yang dilakukan untuk mengetahui pengaruh love of money $\left(\mathrm{X}_{1}\right)$, machiavellian $\left(\mathrm{X}_{2}\right)$, idealisme $\left(\mathrm{X}_{3}\right)$, pada persepsi etis mahasiswa (Y). Model regresi linier berganda ditunjukkan dalam persamaan sebagai berikut:

$\mathrm{Y}=\alpha+\beta_{1} \mathrm{X}_{1}+\beta_{2} \mathrm{X}_{2}+\beta_{3} \mathrm{X}_{3}+\mathrm{e}$

Keterangan:

$\mathrm{Y}=$ Persepsi Etis Mahasiswa Akuntansi

$\alpha=$ Nilai konstanta

$\beta_{1}=$ koefisien regresi dari love of money $\left(\mathrm{X}_{1}\right)$

$\beta_{2}=$ koefisien regresi dari machiavellian $\left(\mathrm{X}_{2}\right)$

$\beta_{3}=$ koefisien regresi dari idealisme $\left(\mathrm{X}_{3}\right)$

$\mathrm{X}_{1}=$ Love of Money

$\mathrm{X}_{2}=$ Machivellian

$\mathrm{X}_{3}=$ Idealisme

e $=$ Standar error

\section{HASIL DAN PEMBAHASAN}

Data penelitian dikumpulkan dengan menyebarkan kuesioer secara langsung kepada mahasiswa akuntansi Fakultas Ekonomi dan Bisnis Universitas Udayana. Penyebaran kuesioner dimulai 28 September 2017 sampai dengan tanggal 1 November 2017. Uji validitas digunakan untuk mengukur sah atau tidaknya suatu kuesioner. Validnya suatu kuesioner dapat dilihat pada kolom Correlated Item Total Correlation, jika nilai pearson correlation lebih besar dari 0,30. Pada penelitian iniseluruh indikator pernyataan dalam kuesioner dengan variabel Love of Money $\left(\mathrm{X}_{1}\right)$, Machiavellian $\left(\mathrm{X}_{2}\right)$, Idealisme $\left(\mathrm{X}_{3}\right)$, Persepsi Etis (Y) memiliki pearson correlation yang lebih besar dari 0,30 sehingga indikato tersebut memenuhi syarat validitas data. 
Suatu kuesioner dapat dikatakan reliabel apabila jawaban dari responden terhadap pernyataan adalah konsisten atau stabil dari waktu ke waktu. Uji reliabilitas dihitung mengunakan uji statistik Cronbach Alpha. Apabila nilai Cronbach Alpha diatas 0,70 maka instrumen yang digunakan dikatakan reliabel. Pada hasil penelitian ini nilai Cronbach Alpha presepsi etis (Y) sebesar 0,838, love of money $\left(\mathrm{X}_{1}\right)$ sebesar 0,909 , machiavellian $\left(\mathrm{X}_{2}\right)$ sebesar 0,829 , dan idealisme $\left(\mathrm{X}_{3}\right)$ sebesar 0,844. Berdasarkan hasil tersebut masing-masing variabel memiliki nilai lebih besar dari 0,70 . Hal ini menunjukkan bahwa semua pertanyaan dalam kuesioner penelitian ini reliabel dan dapat digunakan.

Berdasarkan hasil penyebaran kuesioner sebanyak 200, terdapat 20 kuesioner yang tidak lengkap, sehingga tidak dimasukkan dalam tahap analisis. Total kuesioner yang dipergunakan untuk analisis yaitu sebanyak 180 kuesioner. Rincian jumlah kuesioner yang disebar dan kuesioner yang kembali dapat dilihat pada Tabel 1.

Tabel 1.

Data Penyebaran dan Pengembalian Kuesioner

\begin{tabular}{lc}
\hline \multicolumn{1}{c}{ Keterangan } & Jumlah \\
\hline Kuesioner yang disebar & 200 \\
Kuesioner yang tidak lengkap & 20 \\
Kuesioner yang kembali & 180 \\
Tingkat Pengembalian (response rate) & $90 \%$ \\
Kuesioner yang kembali $x$ & $100 \%=\underline{180} \times 100 \%$ \\
Kuesioner yang disebar & \\
Kuesioner yang digunakan & 180 \\
Tingkat Pengembalian yang digunakan (usable response rate) & $90 \%$ \\
Kuesioner yang diolah $x$ & $100 \%=\underline{180} \times 100 \%$ \\
Kuesioner yang disebar & 200
\end{tabular}

Sumber : Data diolah, 2017 
Putu Pandhu Prabowo dan A.A.G.P Widanaputra. Pengaruh...

Statistik deskriptif yang disajikan dalam penelitian ini adalah untuk memberikan informasi mengenai karakteristik variabel penelitian. Hasil statistik deskriptif pada penelitian ini tertera pada Tabel 2. sebagai berikut.

Tabel 2.

Hasil Statistik Deskriptif

\begin{tabular}{lccccc}
\hline \multicolumn{1}{c}{ Variabel } & $\mathbf{N}$ & Min. & Max. & Mean & Std. Deviasi \\
\hline Love of Money $\left(\mathrm{X}_{1}\right)$ & 180 & 60 & 118 & 81,83 & 11,511 \\
Machiavellian $\left(\mathrm{X}_{2}\right)$ & 180 & 38 & 80 & 53,96 & 7,694 \\
Idealisme $\left(\mathrm{X}_{3}\right)$ & 180 & 20 & 40 & 30,60 & 4,261 \\
Persepsi Etis $(\mathrm{Y})$ & 180 & 13 & 32 & 20,28 & 3,797 \\
\hline
\end{tabular}

Sumber : Data diolah, 2017

Persepsi Etis (Y) nilai minimumnya 13 dan nilai maksimumnya 32. Nilai rata-rata 20,28, artinya jawaban dari responden cenderung setuju pada pernyataan persepsi etis, maka dapat dinyatakan bahwa persepsi etis cenderung tinggi. Standar deviasi pada variabel persepsi etis adalah sebesar 3,79.

Love of Money $\left(\mathrm{X}_{1}\right)$ memiliki nilai minimumnya 60 dan nilai maksimumnya 118. Nilai rata-rata 81,83 , artinya jawaban dari responden cenderung setuju pada pernyataan love of money, maka dapat dinyatakan bahwa love of money cenderung tinggi. Standar deviasi pada variabel love of money adalah sebesar 11,5.

Machiavellian $\left(\mathrm{X}_{2}\right)$ nilai minimumnya 38 dan nilai maksimumnya 80 . Nilai rata-rata 53,96, artinya jawaban dari responden cenderung setuju pada pernyataan perilaku machiavellian, maka dapat dinyatakan bahwa perilaku machiavellian cenderung tinggi. Standar deviasi pada variabel machiavellian sebesar 7,69. 
Idealisme $\left(\mathrm{X}_{3}\right)$ nilai minimumnya 20 dan nilai maksimumnya 40. Nilai rata-rata 30,60 artinya jawaban dari responden cenderung setuju pada pernyataan sifat idealisme, maka dinyatakan bahwa idealisme cenderung tinggi. Standar deviasi pada variabel idealisme sebesar 4,26.

Uji normalitas bertujuan untuk menguji apakah dalam residual dari model regresi yang dibuat berdistribusi normal ataukah tidak (Ghozali, 2013:160). Pada penelitian ini, uji normalitas menggunakan uji statistik yaitu dengan uji Kolmogorov-Smirnov. Jika nilai probability asymp.sig (2-tailed) yang dihasilkan > 0,05 maka data berdistribusi normal. Nilai asymp.sig (2-tailed) pada penelitian ini yaitu $0,059>a=0,05$, maka disimpulkan data dalam penelitian ini berdistribusi normal.

Uji multikolinearitas bertujuan untuk menguji apakah dalam model regresi ditemukan adanya korelasi antar variabel bebas. Apabila nilai VIF kurang dari 10 atau nilai tolerance lebih besar dari 0,1 (10\%), maka dapat dikatakan bahwa tidak ada multikolinearitas. Berdasarkan hasil uji ditunjukkan tolerance masing-masing variabel lebih besar dari 0,1 dan nilai VIF $<10$, maka variabel penelitian ini tidak terjadi multikolinearitas.

Uji heteroskedastisitas bertujuan untuk menguji apakah dalam model regresi terjadi ketidaksamaan hasil dari residual satu pengamatan ke pengamatan yang lain. Berdasarkan hasil uji heteroskedastisitas, dapat diketahui nilai signifikansi dari variabel love of money sebesar $0,717 \quad(>0,05)$, variabel Machiavellian sebesar 0,073 (>0,05), dan variabel idealisme 0,064 (>0,05). Oleh karena probabilitas nilai signifikansi dari masing-masing variabel independen 
Putu Pandhu Prabowo dan A.A.G.P Widanaputra. Pengaruh...

terhadap variabel absolute residual berada diatas 0,05 maka dapat disimpulkan bahwa data yang digunakan pada penelitian ini tidak terdapat masalah heteroskedastisitas.

Tabel 3.

Hasil Analisis Regresi Linear Berganda

\begin{tabular}{|c|c|c|c|c|c|}
\hline \multirow{2}{*}{ Variabel } & \multicolumn{2}{|c|}{$\begin{array}{c}\text { Unstandardized } \\
\text { Coefficients }\end{array}$} & \multirow{2}{*}{$\begin{array}{c}\begin{array}{c}\text { Standardized } \\
\text { Coefficients }\end{array} \\
\text { Beta } \\
\end{array}$} & \multirow[t]{2}{*}{$\mathbf{T}$} & \multirow[t]{2}{*}{ Sig. } \\
\hline & B & $\begin{array}{c}\text { Std. } \\
\text { Error }\end{array}$ & & & \\
\hline (Constant) & 8,411 & 2,623 & & 3,207 & 0,002 \\
\hline Love of Money $\left(\mathrm{X}_{1}\right)$ & $-0,049$ & 0,023 & $-0,148$ & $-2,080$ & 0,039 \\
\hline Machiavellian $\left(\mathrm{X}_{2}\right)$ & 0,165 & 0,036 & 0,334 & 4,579 & 0,00 \\
\hline Idealisme $\left(\mathrm{X}_{3}\right)$ & 0,228 & 0,062 & 0,256 & 3,666 & 0,00 \\
\hline $\begin{array}{l}\text { Adjusted R square } \\
\text { F Hitung } \\
\text { Sig. F }\end{array}$ & & & $\begin{array}{c}0,185 \\
14,547 \\
0,000\end{array}$ & & \\
\hline
\end{tabular}

Sumber : Data diolah, 2017

Hasil pada Tabel 6. Persamaanlregresi linier berganda pada penelitia ini adalah sebagai berikut.

$\mathrm{Y}=8,411-0,049 \mathrm{X}_{1}+0,165 \mathrm{X}_{2}-0,228 \mathrm{X}_{3}$

Pada Tabel 6. hasil uji dalam penelitian ini yaitu 0,000 dengan signifikansi uji $\mathrm{F}$ yaitu 0,000 lebih kecil dari konstanta 0,05, maka model dikatakan layak. Koefisien determinasi Adjusted $R$ Square pada Tabel 6. adalah 0,185 artinya variabel independen (love of money, machiavellian, dan idealisme) memengaruhi sebesar 18,5\% dalam memprediksi variable dependen (persepsi etis), sedangkan $81,5 \%$ dijelaskan oleh faktor lainnya yang tidak di gunakan pada penelitian ini. 
Melihat adanya pengaruh dari variabel independen terhadap variabel dependennya digunakan uji $\mathrm{t}$ dalam menilai hipotesis penelitian. Uji t pada penelitian ini membandingkan nilai signifikansi variabel dengan $\alpha=0,05$.

Hipotesis pertama $\left(\mathrm{X}_{1}\right)$ pada Tabel 6. menunjukkan nilai signifikansi uji $\mathrm{t}$ variabel pengaruh love of money pada persepsi etis sebesar 0,039 lebih kecil dari $\alpha$ $=0,05$ dengan nilai koefisien regresi $-0,049$. Hal ini menunjukan kecenderungan love of money seseorang semakin tinggi, maka presepsi etis semakin rendah, sehingga hipotesis pertama dalam penelitian ini diterima.

Tingkat love of money yang tinggi dapat memengaruhi presepsi etis mahasiswa akuntansi. Teori presepsi yang dikembangkan Robbins dan Judge (2008) menyatakan bahwa sikap seseorang dapat memengaruhi persepsinya. Individu dengan sifat love of money yang berlebihan akan memiliki pandangan bahwa uang adalah suatu kebutuhan yang harus dipenuhi sehingga akan sangat berambisi dengan melakukan berbaga cara untuk memperoleh uang. Penelitian ini mendapat hasil penelitian yang sama dengan Tang dan Chiu (2003) yaitu love of money berpengaruh negatif pada presepsi etis. Sejalan pula dengan hasil penelitian Elias (2010) yang mneyatakan kecintaan seseorang pada uang berpengaruh signifikan pada perilaku tidak etis.

Hipotesis kedua $\left(\mathrm{X}_{2}\right)$ pada Tabel 6. menunjukkan nilai signifikansi uji t variabel pengaruh machiavellian pada kinerja auditor adalah $0,000<\alpha=0,05$, nilai koefisien regresi memiliki nilai sebesar 0,165. Sifat machiavellian seseorang yang tinggi menunjukan presepsi etisnya juga akan semakin tinggi, sehingga hipotesis kedua dalam penelitian ini ditolak. 
Putu Pandhu Prabowo dan A.A.G.P Widanaputra. Pengaruh...

Peran lingkungan serta perkembangan zaman membuat pola pikir mahasiswa akuntansi melakukan hal yang tidak etis seperti memanipulasi dengan tujuan tertentu. Kurangnya pendidikan tentang kedisiplinan serta penerapan etika menjadikan mahasiswa akuntansi Unud tidak memiliki rasa kepercayaan diri yang cukup dan tanggung jawab dalam menjalani perkuliahan, hal ini dapat dilihat dari hasil pengisian kuesioner dengan tingkat kecenderungan machiavellian yang tinggi. Penelitian ini mendapat hasil yang tidak sama dengan Purnamasari (2006) menunjukkan hasil bahwa perilaku machiavellian auditor semakin tinggi maka penyimpangan terhadap presepsi etis juga cenderung akan tinggi. Kelly Ann Richmond (2001) memperoleh hasil penelitian yang sama yaitu perilaku machiavellian berpengaruh signifikan dalam mengambil keputusan yang etis apabila dalam diri sendiri terdapat dilema etis.

Hipotesis ketiga $\left(\mathrm{X}_{3}\right)$ pada Tabel 6. Menunjukkan nilai signifikansi uji t variabel pengaruh idealisme pada persepsi etis $0,000<\alpha=0,05$, nilai koefisien regresi 0,228 . Hasil menunjukan semakin idealis seseorang maka semakin tinggi persepsi etisnya, sehingga hipotesis ketiga dalam penelitian ini ditolak.

Setiap orang memiliki idealisme yang berbeda-beda, karena pada dasarnya paham idealisme tidak muncul secara mendadak melainkan melalui beberapa tahapan. Semakin seseorang memiliki banyak pengalaman, maka semakin tinggi pula idealisme yang ada dalam dirinya. Begitu pula dengan mahasiswa akuntansi Unud yang memiliki idealisme berbeda-beda, tingkat pengambilan keputusan etis dipengaruhi seberapa besar idealisme yang ada pada setiap individu. Sejalan 
dengan hasil penelitian Nugroho (2008) menyatakan idealisme mahasiswa tidak memengaruhi opini dari mahasiswa kepada auditor.

Idealisme tinggi yang dimiliki oleh mahasiswa tidak dapat digunakan sebagai tolok ukur dalam memberi penilaian tidak etisnya perilaku akuntan dengan lebih tegas. Kurang pahamnya mahasiswa tentang etika dan proses dalam mempelajari etika dianggap belum efektif, apabila mahasiswa menghadapi sebuah kasus terkait pelanggaran, maka mahasiswa cenderung tidak tegas dalam memberi pada persepsi atau penilaian. Penelitian ini bertolak belakang dengan hasil penelitian Comunale et al., (2006), dimana idealisme berpengaruh pada presepsi mahasiswa pada perilaku auditor. Tingkat idealisme mahasiswa yang tinggi akan berpengaruh pada penilaian tindakan auditor secara tegas.

Implikasi pada penelitian ini terdiri dari impilikasi teoritis dan imlikasi praktis. Implikasi teoritis pada penelitian ini adalah hasil penelitian ini diharapkan dapat memberikan tambahan informasi mengenai pengaruh love of money, Machiavellian, dan idealisme pada persepsi etis mahasiswa akuntansi. Terdapat bukti empiris bagi peneliti dalam pengaruh love of money, machiavellian, dan idealisme berhubungan dengan persepsi etis. Hasil penelitian ini dapat membantu para akademisi dalam melihat sudut pandang mahasiswa akuntansi terkait suatu kasus dan bagaimana berdampak pada minat mahasiswa dalam bidang akuntansi. Impikasi praktis pada penelitian ini adalah diharapkan memberi pengertian kepada pembaca, khususnya mahasiswa, dimana mereka harus memiliki perilaku etis sebelum masuk ke dunia kerja. Selain itu, penelitian ini dapat membantu manajemen perusahaan mana pun yang menawarkan pekerjaan sebagai akuntan 
Putu Pandhu Prabowo dan A.A.G.P Widanaputra. Pengaruh...

yang memerlukan persepsi etis dalam rekruitmentnya. Penelitian ini diharapkan dapat mempersiapkan perilaku etis sebelum memasuki dunia kerja.

\section{SIMPULAN}

Berdasarkan hasil pembahasan penelitian diatas, simpulan dari penelitian ini yaitu tingginya kecenderungan love of money individu maka presepsi etisnya semakin rendah. Tingginya machiavellian maka tidak semakin rendah pula persepsi etisnya. Semakin idealis individu maka tidak semakin rendah pula persepsi etisnya.

Saran yang dapat diberikan dari hasil penelitian dan kesimpulan diatas yaitu mahasiswa akuntansi harus menggunakan etika dan norma yang berlaku untuk meraih suskses, di barengi juga dengan peningkatan prestasi belajar dan pengembangan akan kemampuan diri sendiri. Bagi peneliti selanjutnya disarankan dapat memperluas ruang lingkup dengan menambah beberapa variabel diluar dari penelitian ini agar dapat mengetahui hal apa saja yang mempengaruhi persepsi etis seseorang.

\section{REFERENSI}

Arens, Alvin A., Elder, Randal J. dan Beasly, Mark S. (2006). Auditing dan Jasa Assurance. Jakarta: Erlangga.

Charismawati, C.D. (2011). Analisis Hubungan antara Love of Money dengan Persepsi Etika Mahasiswa Akuntansi. Skripsi Akuntansi Universitas Diponogoro.

Comunale, C., Thomas, S. and Stephen, C. 2006. Professional Ethical Crises:A Case Study of Accounting Majors. Managerial Auditing Journal, Vol. 21, No. 6, pp 636-656. 
Dzakirin, M. Khairul.2013.”Orientasi Idealisme, Relativisme, Tingkat Pengetahuan, dan Gender: Pengaruhnya pada Persepsi Mahasiswa tentang Krisis Etika Akuntan Profesional”.

Elias, R. Z. dan Farag. M. S. (2010). The Reletionship Between Accounting Stundents' Love Of Money And Their Ethical Perception. Managerial Auditing Journal, Vol. 25 Iss: 3,pp269-281.

Falah, S. (2006). Pengaruh Budaya Organisasi dan Orientasi Etika Terhadap Sensitivitas Etika (Studi Empiris Tentang Pemeriksaan Internal di Bawasda Pemda Papuan). Simposium Nasional Akuntansi X.

Forsyth, D. (1992). "Judging the Morality of Business Practices : the Influence of Personal Moral Philosophies”. Journal of Business Ethics, Vol 11, pp 416470.

Hayes, J. V. (2006). Money Attitudes Economic Locus of Control and Financial Strain Among College Students." A Desetation. Texas Tech University.

Hazeberg, F. (1987). One more time: How do you motivate employees? Harvard Business Review, 65(September-October). 109-120.

Jalaludin Rakhmat. (1999). Psikolohi Komunikasi. Bandung: PT Remaja Rosdakarya.

K.T. Yamauchi \& Templer, D. (1982). The Development of Money Attitude Scale. Journal of Personality Assessment.

Lois O. Katt Soff. (1953). Elements of Philosophy. New York: The Ronald Press Company.

Mitchell, T. R., dan Mickel, A. 1999. The meaning of money: an individual difference perspective. The Academy of Management Review, 24, 568578 .

Murwanto. 2007 Pengaruh Pemikiran Moral, Tingakat Idealisme, Tingkat Relativisme dan Locus Of Control Terhadap Sensitivitas, Pertimbangan, Motovasi dan Karakter Mahasiswa Akuntansi. Universitas Diponegoro, Semarang.

Normadewi, Berlian. (2012). Analisis Pengaruh Jenis Kelamin dan Tingkat Pendidikan terhadap Persepsi Etis Mahasiswa dengan Love of Money sebagai Variabel Intervening. Undergraduate thesis.Universitas Diponogoro. 
Putu Pandhu Prabowo dan A.A.G.P Widanaputra. Pengaruh...

Nugroho, B. 2008. Faktor-Faktor yang Mempengaruhi Penilaian MahasiswaAkuntansi atas Tindakan Auditor dan Coorporate Manager dalam Skandal Keuangan serta Tingkat Ketertarikan Belajar dan Berkarier di BidangAkuntansi. Tesis. Fakultas Ekonomi Universitas Diponegoro

Nurcahyo, Immanuel Oky.2012.’'Idealisme, Relativisme, dan Kreativitas Akuntan”. katalog.library.perbanas.ac.id.

Purnamasari, St.Vena dan Agnes Advensia C. (2006). Dampak Reinforcement Contingency Terhadap Hubungan Sifat Machiavellian dan Perkembangan Moral. Padang: Simposium Nasional Akuntansi XI.

Richmond, Kelly Ann. (2003). Ethical Reasoning, Machiavellian Behavior, and Gender: the Impact on Accounting Students' Ethical Decision Making.Dissertation. Virginia Polytechnic Institute.

Rowe, A.J. dan J.D.Boulgarides. (1992). Managerial Decition Making. New York: Macmillan Publishing Company.

Smith, B. (2009). Ethical Ideology And Cultural Orientation: Understanding The Individualized Ethical Inclinations Of Marketing Student . American Journal of Bussines Education, Vol. 2, No. 8, Hal: 27-36.

Sugiyono. (2016). Metodologi Penelitian Kuantitatif Kualitatif dan $R \& D$. Bandung: Alpha Beta.

Sumiyantini, Ni Kadek. (2017). Persepsi Mahasiswa Jurusan Akuntansi Mengenai Idealisme, Relativisme, dan Tingkat Pengetahuan Pada Perilaku Tidak Etis Akuntan (Studi Pada Mahasiswa Jurusan Akuntansi Universitas Pendidikan Ganesha). e-journalS1 Ak Universitas Pendidikan Ganesha Jurusan Akuntansi Program S1, Vol. 7 No. 1 Tahun 2017.

Tang , T.L.P. and Chen,Y.J. (2008). Inteleligence vs Wisdom: The love of Money, Machiavellianism and Unethecial Behavior Across College Major and Gender . Journal of

Tang, T.L.P. and Chiu, R.K. (2003). Income Money Ethic, Pay, Satisfaction,Commitment, and Unethical Behaviour: Is the Love of Money The Root of Evil for Hongkong Employees ? Journal Business Ethic, Vol. 46, pp. 542-8.

Triandis, Harry. C. (1971). Attitude and Attitude Change. Toronto: John Wiley and Sons. 
Utami, Diah Ratnasari. (2005). “Analisis Perbedaan Faktor-Faktor Individual Terhadap Persepsi Perilaku Etis Mahasiswa:Studi Kasus pada Mahasiswa dan Manajemen di Perguruan Tinggi Se- Karesidenan. Jurnal Akuntansi dan Auditing, Vol. 1 No. 2 Hal. 162-180.

Yeltsinta, Ratih. (2013). Love of Money, Pertimbangan Etis, Machiavellian,Queationable Action: Implikasi Pengambilan Keputusan Etis Mahasiswa Akuntansi dengan Variabel Moderasi Gender. Undergraduate thesis. Universitas Diponogoro. 